\title{
(Re)construindo práticas docentes: o ensino de Língua Portuguesa e Literatura na Educação Básica
}

\author{
Henrique Miguel Lima Silva ${ }^{\mathrm{i}}$
}

NASCIMENTOS, Erivaldo Pereira do; SALES, Laurência Souto. (Re)construindo práticas docentes: o ensino de Língua Portuguesa e Literatura na Educação Básica. João Pessoa: EDUFPB, 2017.

Publicado pela editora da Universidade Federal da Paraíba, o livro (Re)construindo práticas docentes: o ensino de Língua Portuguesa e Literatura na Educação Básica reúne textos que buscam diretamente a melhoria do ensino de língua portuguesa e literatura na educação básico, bem como a, inerente, necessidade de (re)pensarmos a formação de professores com ênfase na práxis, isto é, práticas profissionais ancoradas em teorias linguístico-discursivas e didáticas que, por sua vez, ressignificam os processos de ensinoaprendizagem e, dessa maneira, contribuem na formação de sujeitos críticos, ativos e autores de sua própria história.

Decorrente de inúmeras reflexões e discussões dos diversos grupos de pesquisa dos quais os colaboradores do livro fazem parte, bem como diante das novas demandas de ensino considerando as preconizações dos Parâmetros Curriculares Nacionais (BRASIL, 1996) e, atualmente, a ampliação das discussões sobre formação em língua materna com a promulgação da Base Nacional Comum Curricular (BRASIL, 2017). Salientamos que estes documentos defendem a premissa do ensino de língua portuguesa a partir dos gêneros textuais, das práticas de letramento e com foco na construção da proficiência em língua materna.

Todas as discussões teóricas oriundas destes documentos implicam diretamente no processo de formação de professores que, mais do que nunca, precisa ter uma formação voltada para a práxis e, portanto, passa a ser uma necessidade que urge nas academias. Tais discussões teórico-metodológicas são, assim, discutidas na obra em questão.

Organizado pelos professores Erivaldo Pereira do Nascimento e Lauênia Souto Sales, a referida obra evidencia uma série de pesquisas oriundas do Mestrado Profissional em Letras (PROFLETRAS) da Universidade Federal da Paraíba - UFPB/Campus Mamanguape no tocante aos processos de formação de professores, considerando, portanto, as pesquisas decor-

\footnotetext{
${ }^{\mathrm{i}}$ Universidade Federal da Paraíba (UFPB). E-mail: henrique.miguel.91@gmail.com.
} 
-rentes de práticas exitosas construídas pelos referidos pesquisadores, sendo, portanto, indispensáveis para o desenvolvimento das novas possibilidades teórico-práticas voltadas para a práxis.

Destaca-se ainda coerência dos trabalhos reunidos na obra com as demandas e dilemas contemporâneos do ensino de língua portuguesa e literatura na educação, bem como dos desdobramentos para a melhoria qualitativa dos cursos de formação de professores, e da contribuição destas pesquisas para o desenvolvimento da educação básica no cenário brasileiro.

Além da apresentação, este livro comporta dez capítulos, em 331 páginas, na qual a primeira parte reflete sobre as demandas do ensino de produção textual e didatização de gêneros, enquanto a outra metade se desdobra no ensino de leitura e reflexões sobre a ação docente considerando as tecnologias e tendências contemporâneas do ensino. Outro aspecto que merece destaque consiste na linguagem acessível, contemplando as discussões teóricas e práticas voltadas para o ensino de língua e literatura na educação básica.

Neste sentido, a obra contribui de modo significativo para a formação de nível superior, tanto na graduação como na pós-graduação lato e stricto sensu considerando os desdobramentos nos eixos de formação de professores, ensino, pesquisa e extensão.

Neste sentido, no primeiro capítulo, "O processo de construção de sentidos no debate de opinião de fundo controverso - uma experiência no Ensino Fundamental”, Gracilene Barros de Oliveira de Erivaldo Pereira do Nascimento se debruça sobre uma experiência realizada em sala de aula considerando a sequência didática enquanto planejamento para a atuação docente, bem como defendendo esta prática como indispensável para construção da práxis docente e da autonomia do discente da educação básica sendo, portanto, indispensável para melhoria da educação básica a partir das práticas exitosas socializadas neste capítulo.

No segundo capítulo, “Oralidade em sala de aula para além dos gêneros informais: uma proposta interventiva com o gênero debate de opinião", Fernando Alves de Oliveira e Roseane Batista Feitosa Nicolau evidenciam a didatização do gênero debate de opinião com base na sequência didática, bem como focalizam os aspectos linguísticos do trabalho com o gênero em questão. Neste capítulo, os autores discutem as etapas de análise e produção do gênero textual, contribuindo diretamente na formação em educação básica e no desenvolvimento das competências linguístico-discursivas dos discentes envolvidos neste processo de ensino-aprendizagem.

No terceiro capítulo, "Os desafios da (re)escrita do gênero notícia: uma prposra de sequência didática”, Mara do Carmo Melo Aguiar Neta e Laurênia Souto Sales evidenciam os 
pressupostos teóricos e metodológicos do Interacionsimo Sociodiscursivo (ISD) para a elaboração de sequência didática, bem como dos desdobramentos desta metodologia para a melhoria qualitativa dos processos de ensino-aprendizagem de língua portuguesa na educação básica. Nesta proposta, as autoras discutem a relevância ISD à prática docente, bem como a práxis de formação e as interações decorrentes deste processo.

No quarto capítulo, "Reflexões sobre o trabalho com o gênero carta pessoal na Educação de Jovens e Adultos", Lindolfo Santos Ramalho e Joseval dos Reis Miranda apesentam os resultados da pesquisa desenvolvida no Profletras e contribuem diretamente no desenvolvimento das práticas de produção textual na EJA, bem como nas reflexões sobre o trabalho docente nesta modalidade de ensino. De forma dinâmica, os autores convidam os leitores a repensarem sua ação docente no contexto da EJA.

No quinto capítulo, “Anúncio publicitário no ensino fundamental: uma proposta para a produção textual”, Alanna Cavalcanti dos Santos Silva e Carla Alecsandra de Melo Bonifácio discutem sobre as contribuições de didatização dos gêneros textuais para a melhoria qualitativa da aprendizagem em língua materna. Para isto, as autoras relatam uma prática exitosa de leitura e produção textual no $9^{\circ}$ ano do ensino fundamental nesse sentido, as contribuem com os estudos sobre multimodalidade e ensino de línguas.

$\mathrm{Na}$ segunda parte da obra, os trabalhos se desdobram sobre os eixos da leitura e formação crítica dos professores nas aulas de língua portuguesa e literatura. No sexto capítulo, "Leitura na EJA a partir dos procedimentos de leitura na Prova Brasil", Edenia Cesarina de Brito e Alvanira Lucia de Barros analisam as dificuldades de desenvolvimento das competências leitoras na EJA e discutem possiblidades de fortalecimento da formação crítica com ênfase na leitura, nos resultados da Prova Brasil e na, inerente, necessidade de repensarmos a práxis docente.

No sétimo capítulo, "Os círculos de leitura literária: uma proposta de trabalho com o gênero mito", Aline Teixeira Cavalcanti Sette e Luciane Alves Santos, refletem sobre a relevância do trabalho com o texto literário e suas contribuições na formação de leitores críticos e proficientes, bem como da necessidade de desenvolver propostas de ensino que fortaleçam a aprendizagem na EJA e, dessa maneira, contribuam diretamente com o estado da arte da literatura em questão.

No oitavo capítulo, "Reflexões e ações interventivas em sala de aula: uma proposta de ensino de leitura com o gênero poema”, Francisca e Vânia Rocha Nóbrega e Marineuma de Oliveira Costa Cavalcanti propõem a utilização do gênero poema enquanto meio de pedagógico para fortalecimento da leitura e, para isto, consideram as teorias do letramento 
enquanto proposta teórico-metodológica e, neste sentido, corroboram a socialização de práticas de fortalecimento das aprendizagens significativas em língua e literatura portuguesa.

No nono capítulo, "Wequest: metodologia direcionada de pesquisa na internet", Maria Patrícia Cavalcanti e João Wandemberg Gonçalves Maciel refletem sobre as contribuições das tecnologias no ensino de língua materna e colaboram diretamente na construção do senso investigativo dos discentes da educação básica, promovendo, dessa maneira ressignificações no ensino de língua materna.

O último capítulo, "A constituição discursiva de identidades linguísticas: uma proposta de trabalho para as aulas de Língua Portuguesa", Itânia Flávia da Silva e Marluce Pereira da Silva propõem novos olhares sobre o ensino de língua materna a partir da construção crítica das identidades linguísticas e, para isto, consideram as teorias do letramento; a língua enquanto interação social e o docente enquanto agente de letramento e, dessa maneira, de transformação crítica da sociedade com base no conhecimento linguístico. Portanto, além de contribuir na formação, os autores corroboram ativamente na construção de aprendizagens significativas.

Podemos observar que este livro contribui diretamente com o estado da arte, bem como na ressiginificação dos processos de formação de professores de modo crítico, dinâmico e interativo. Destaca-se, portanto: a) caráter teórico-metodológico do livro e seus desdobramentos na melhoria da educação básica b) consolidação de pesquisas desenvolvidas sob diversas perspectivas teórico-metodológicas que fortalecem o ensino de língua portuguesa e literatura no Brasil e, por fim, c) a contribuição destes estudos na transformação dos paradigmas da educação básica e do processo de formação de professores de língua materna.

Assim, o referido livro evidencia resultados de intervenções exitosas que, por sua vez, possibilitam novos olhares do/no/para o ensino de língua e literatura. É justamente com base nas pesquisas descritas que a leitura desta obra é de grande valia para pesquisadores da Linguística, Literatura e Ensino considerando, portanto, estudantes e pesquisadores graduação e pós-graduação. 